\title{
Predicting The Occupational Choices Of Foreign-Born And Second-Generation Canadians: Evidence From Census Data
}

Najma R. Sharif, Saint Mary's University, Canada

\begin{abstract}
In this paper, we study the occupational mobility of immigrants and the intergenerational transfer of their occupational status in Canada. The former is done by predicting their occupational choices and examining shifts in those choices as the length of residence in Canada increases, while the latter is studied by comparing the choices of immigrants with those of second-generation Canadians. Of special interest is the role that gender plays in this regard. We use the SchmidtStrauss (1975) multinomial logit model to explain occupational choice in terms of human capital \& other characteristics with additional controls for immigration status, and the length of residence in Canada. This model is estimated using data from the public-use micro-data files from the 2001 Canadian Censuses, and then used in a simulation context to predict the occupational profiles of all native-born, foreign-born and second-generation Canadian men and women in the aggregate, and also of various cohorts of immigrants.
\end{abstract}

Keywords: occupational choice; logit model; second-generation and foreign-born men and women

\section{INTRODUCTION}

¿

mmigrant labour market experiences in North America are the subject of a vast literature, both theoretical and empirical, especially in the United States. Much of the emphasis has been on explaining native-bornimmigrant differentials in a number of labour market outcomes, such as wages, and the focus has been on assessing whether immigrants converge to host country norms as the length of residence increases [see, for instance, Borjas (1985)]. A similar literature has also emerged in Canada [Bloom and Gunderson (1990), Baker and Benjamin (1994), Prescott and Wandschneider (1995), Worswick (1996), Hum and Simpson (2004), and Sharif and Dar (2007)]. Canadian immigration policy has favoured skilled immigration for many years now, rather than immigration for family reunification. Although this might lead to better educational attainments for immigrants compared to the native-born [Aydemir and Sweetman (2006)], this need not translate into better labour market outcomes because the foreign-born may face a host of problems, ranging from language difficulties to nonrecognition of foreign-acquired credentials. These would impact adversely on labour market outcomes.

In this paper, our focus is on occupational choice as an important indicator of an individual's status in labour markets. We examine whether there are significant differences in the occupational choices that otherwise similar individuals make, after we control for human capital and other relevant characteristics. Of special interest is the question of how the occupational patterns of the foreign-born differ from those of the native-born, whether the length of residence in Canada has implications for the occupational mobility of the former, and what role does gender play in this regard. We also examine the question of the inter-generational transfer of occupational status by comparing the occupational profiles of foreign-born and second-generation Canadians. The latter are native-born with one or both foreign-born parents.

Our interest also lies in assessing the role that human capital characteristics, such as field of study and language ability (of foreign-born only), affect the occupational profile of foreign-born men and women. We use the Schmidt-Strauss (1975) multinomial logit model and explain occupational choice in terms of human capital \& other 
characteristics with additional controls for immigration status, and the length of residence in Canada. This model is estimated using data from the public-use micro-data files from the 2001 Canadian Censuses, then used in a simulation context to examine how the occupational profiles of all native-born, foreign-born and second-generation Canadian men and women differ, and how the length of residence in Canada affects the occupational mobility of immigrant men and women as they become more accustomed to Canadian labour markets.

New immigrants potentially face a number of problems, from unfamiliarity with Canadian labour markets and institutions, the lack of language fluency, limited access to occupational networks, except perhaps in ethnic labour markets, and foreign-acquired credentials that are often not recognized. The problem of non or under recognition of immigrant credentials, especially in the heavily regulated medical, health and engineering professions, has been well recognized in Canada [see, for instance, Boyd (2000)]. These problems would suggest that immigrants, particularly from non-traditional sources, could suffer from prolonged search unemployment, underemployment, and withdrawal from the labour force, a mismatch between occupational choice \& educational training, and disproportionate concentration in non-managerial and non-professional occupations.

In Canada, these issues are of policy relevance for several inter-related reasons. First, demographic trends in the country suggest that immigration will likely be an even more significant contributor to labour force growth in the years ahead and successful labour market outcomes of the foreign born, including their ability to match occupation to skills, has important implications for their well-being and their integration into Canadian society. Secondly, in a related context, the study of second-generation Canadians would also shed light on the intergenerational mobility of occupational status, whether the children of the foreign-born adapt well to Canadian labour markets. Third, the differences in male-female occupational profiles would also point to the avenues through which gender inequities in labour market outcomes operate. Thus, Sharif (2006), who examined the employment status of South Asian and Chinese immigrants, found that the employment profiles of these groups is generally inferior to that of the native-born in that they are more likely to be unemployed, employed part-time or out of the labour force, and that this adverse impact is larger for women. Beach and Worswick (1993) also found that there is a "double-negative" impact on the wages of women immigrants to Canada.

The rest of the paper is organized as follows. In Section 2, we discuss the data used in this study, outline the estimation model and strategy, analyse our estimates as well as discuss our simulation results. Section concludes by summarizing the findings and drawing some policy implications.

\section{THE DATA, EMPIRICAL MODEL AND RESULTS}

The data used in the study are drawn from the public-use 2001 Canadian census files for individuals. Our sample consists of women aged 25-64 years, which allows us to restrict our attention to those who have completed a significant (if not all) part of their formal schooling and who are not of retirement age. Based on the national occupational classification reported in Canadian censuses, we classify women workers into four major occupational categories: (1) Managers, (2) Professionals, semi-professionals and technicians (Professionals for short), (3) Supervisors, administrative and senior sales and service workers, and skilled crafts and trades workers (Supervisors for short), and (4) Clerical, intermediate sales, other and service workers, and manual workers (Clerical for short). On average, the skill level and wage rates rise as we move from the fourth category to the first category. Table 1 presentssome summary statistics to highlight actual occupational patterns, as well other economic and demographic characteristics of each of the groups of interest in this study.

It is evident from the table that foreign-born men and women are older than their native-born counterparts by an average of about 2-3 years, with second-generation Canadians being the youngest. Men and women within each group are also similar in terms of marital status, location and education. Across the groups, second-generation men and women are least likely to be married, and have the highest years of schooling (about 14 years). Foreignborn and all native-born men and women have about the same level of educational attainment. Unemployment rates are highest among native-born men and lowest among second-generation men and women, while occupational patterns differ across both groups and gender, especially for the managerial and clerical categories. Thus, secondgeneration men and women are more relatively more concentrated in management and least in clerical positions, while the opposite is true for foreign-born women. On the other hand, men are clearly more likely to in managerial 
positions and less likely to be in clerical positions regardless of which group they belong to. It is also seen that a large proportion (about 97\%) of foreign-born men and women say they have knowledge of one or both official languages.

Table 1: Statistical Overview: Selected Economic and Demographic Characteristics - 2001 Census

\begin{tabular}{|c|c|c|c|c|c|c|}
\hline (2) & $\begin{array}{c}\text { Native-born } \\
\text { women }\end{array}$ & $\begin{array}{l}\text { Foreign- } \\
\text { born } \\
\text { Women } \\
\end{array}$ & $\begin{array}{c}\text { Second - } \\
\text { generation } \\
\text { women }\end{array}$ & $\begin{array}{c}\text { Native-born } \\
\text { men }\end{array}$ & $\begin{array}{l}\text { Foreign- } \\
\text { born } \\
\text { men }\end{array}$ & $\begin{array}{c}\text { Second - } \\
\text { generation } \\
\text { men }\end{array}$ \\
\hline Age (years) & 41.1 & 43.0 & 40.2 & 41.3 & 43.9 & 40.3 \\
\hline Married (\%) & 70.5 & 73.3 & 67.0 & 71.8 & 79.1 & 67.8 \\
\hline CMA residents $(\%)$ & 60.1 & 88.8 & 74.6 & 59.1 & 89.0 & 74.8 \\
\hline Years of schooling & 13.4 & 13.7 & 14.3 & 13.4 & 13.9 & 14.2 \\
\hline \multicolumn{7}{|l|}{ Labour Market } \\
\hline Employed (\%) & 89.8 & 88.8 & 90.0 & 91.0 & 91.1 & 92.6 \\
\hline Unemployed (\%) & 3.9 & 4.3 & 3.2 & 5.0 & 4.1 & 3.4 \\
\hline Not in labour force $(\%)$ & 6.4 & 7.7 & 6.8 & 3.9 & 3.8 & 4.0 \\
\hline \multicolumn{7}{|l|}{ Occupation } \\
\hline Managers (\%) & 8.9 & 8.1 & 10.0 & 14.5 & 14.4 & 17.1 \\
\hline Professionals (\%) & 28.6 & 25.0 & 31.8 & 20.7 & 25.2 & 25.6 \\
\hline Supervisors (\%) & 19.1 & 16.6 & 18.9 & 27.4 & 24.3 & 24.7 \\
\hline Clerical $(\%)$ & 43.4 & 50.3 & 39.3 & 37.4 & 36.1 & 32.6 \\
\hline $\begin{array}{l}\text { Knowledge of official } \\
\text { language }(\%) \\
\text { (foreign-born) }\end{array}$ & $*$ & 96.8 & $*$ & $*$ & 97.3 & $*$ \\
\hline Sample size & 115917 & 31789 & 21109 & 123044 & 34302 & 22253 \\
\hline
\end{tabular}

For each of the foreign-born groups as well as all the native born and second-generation Canadians, we first explain how occupational choice is determined. Since occupational choice is measured as a qualitative variable with 4 categories, a logit model with multiple choices appears to be the correct method. The multinomial logit model is of the form:

$\left.\log \left(\pi_{\mathrm{ij}} / \pi_{\mathrm{im}}\right)\right]=\beta_{\mathrm{j} 0}+\Sigma \beta_{\mathrm{jk}} X_{\mathrm{ik}}$

where $\left(\pi_{\mathrm{ij}} / \pi_{\mathrm{im}}\right)$ is the probability of individual $\mathrm{i}(=1,2,3, \ldots, \mathrm{n})$ being in category $\mathrm{j}(=1,2,3, \ldots, \mathrm{J})$ relative to the probability of being in some reference category $\mathrm{m}$, the $\beta \mathrm{s}$ are the coefficients, and the $\mathrm{X}_{\mathrm{k}}(\mathrm{k}=1,2,3 . ., \mathrm{K})$ are the $\mathrm{K}$ control variables. The signs of the impact coefficients indicate the direction of impact on the probability of being in category $\mathrm{j}$ relative to the probability of being in the reference category $\mathrm{m}$ [see, for instance, Schmidt and Strauss (1975) or Greene (1997) for the multinomial logit model and its interpretation and use].

The probability of observing any category, conditional on any specified vector of characteristics, can then easily be obtained from the following:

$\pi_{\mathrm{ij}}=\exp \left(\beta_{\mathrm{j} 0}+\Sigma \beta_{\mathrm{jk}} X_{\mathrm{ik}}\right) / \Sigma \exp \left(\beta_{\mathrm{j} 0}+\Sigma \beta_{\mathrm{jk}} X_{\mathrm{ik}}\right)$

where, using the Theil normalization (that is, using the fourth category - Clerical workers - as the benchmark for comparison), we have $\beta_{40}=0$, and $\beta_{4 \mathrm{k}}=0$ for all $\mathrm{k}$. Equation (1) was estimated by the method of maximum likelihood using data from the 2001 census using the four-category classification of occupations noted above.

Before we discuss our findings, we briefly discuss the choice of explanatory variables. In all logit regressions, human capital characteristics were considered the primary determinants of occupational choice. A person's schooling is likely to have an impact on occupational choice, but that impact is likely to reflect an individual's field of study as well. In light of this, we distinguished between individuals who did not have a postsecondary education from those who had; the latter were then further broken down by field of study. The fields chosen were: Arts, humanities and social sciences (Arts for short); Commerce, management and business 
administration (Business for short); Engineering and Sciences, the latter including agricultural, biological, nutritional and food sciences, and mathematics, computer and physical sciences (Engineering for short); Health, which includes the health profession and related technologies; and a residual category (Other), which includes recreational, educational and counselling services. These are all binary variables, with the default being an individual with no post-secondary education. One would expect that a post-secondary education makes it more likely that individuals would be in management, professional and supervisory positions, and less in clerical positions, with the impact varying across field of study. For instance, one might expect that those with a background in business or engineering and sciences to be the most likely to be in management or the professions.

We also included the age of an individual (measured in years), which captures labour market experience and it is likely that older workers are more likely to be in managerial and professional positions, other things being equal. For the foreign-born, language ability is likely to be an important determinant of the quality of their human capital in Canada. The language ability variable is also a binary variable, with default case being a foreign-born individual who knows at least one official language. The final variable that would affect human capital is the length of residence of the foreign-born in Canada. One would expect that as length of residence in increases, immigrants' human capital becomes more suited to the Canadian labour market, and this is reflected in their occupational choices. Essentially, the impact of the length of residence on occupational choice is a way of assessing the occupational mobility of new and older immigrants relative to that of all native-born as well as second-generation Canadians. To assess how foreign-born occupation patterns change as the length of residence in Canada increases, we introduced a number of variables in the foreign-born logit regressions to capture these effects. Specifically, we defined four immigrant cohorts, reflecting the vintage of the foreign-born. We defined "new" immigrants as those who arrived in Canada between 1996-2001inclusive. The older cohorts were then defined as those arriving during 1991-1995, those arriving during 1986-1990 and those who arrived prior to 1986. We introduce these as binary variables (the pre-1986 cohort being the default group).

We also controlled for person's location, marital status, and for whether the worker was self-employed or a wage worker. Specifically, the location variable is a binary variable equal to 1 if the person resided in a census metropolitan area (CMA), and zero otherwise. Marital status and type of worker effects were also captured by binary variables respectively assuming the value 1 if the person was married or was self-employed, and otherwise

\section{Regression Results}

The estimated logit models for native-born, foreign-born and second-generation women are presented in Table 2, while the corresponding estimates for men are is Table 3. From Table 2, it can be seen that for both nativeborn, foreign-born and second-generation women, those with a post-secondary education are more likely to be managers or professionals (relative to clerical workers) regardless of field of specialization, but less likely to be in the supervisors category if their field of study is health. All the relevant coefficients are statistically significant at the five percent level or less. Self-employed women are also more likely to be in all occupational categories relative to the clerical category, while marital status generally has a similar effect. The impact of age varies by occupation and group. For instance, for second-generation women, age has no statistically significant impact on the probability of being in management relative to the clerical category, but a negative impact on the probability of being in the professional category and a positive impact of being in the supervisors category, all relative to the clerical category.

For foreign-born women, not knowing English or French has a negative effect on the probability of being in management, as well as in the professional and supervisors categories. These effects are statistically significant at the 1 percent level. In addition, compared to established immigrants (the pre-1986 cohort), those of more recent vintage (the 1986-1990, 1991-1995 and 1996-2001 cohorts) are less likely to be managers, professionals or supervisors, relative to clerical workers, and the relevant coefficients are highly significant at the 1 percent level. The biggest difference is between cohorts that have been in Canada 10 or more years and those that have been in Canada less than 10 years, as is clear from the sizes of the estimated coefficients. This would point to greater occupational mobility as new immigrant women accumulate greater experience in the labour market. 
Table 2: Multinomial Logit Estimates of Occupational Choice - Women

\begin{tabular}{|c|c|c|c|c|c|c|c|c|c|}
\hline & \multicolumn{3}{|c|}{ Native-Born } & \multicolumn{3}{|c|}{ Foreign-Born } & \multicolumn{3}{|c|}{ Second-Generation } \\
\hline & $\begin{array}{c}\text { Managers } \\
\text { vs. } \\
\text { Clerical } \\
\text { workers }\end{array}$ & $\begin{array}{c}\text { Profs } \\
\text { vs. } \\
\text { Clerical } \\
\text { workers }\end{array}$ & $\begin{array}{c}\text { Supervisors } \\
\text { vs } \\
\text { Clerical } \\
\text { workers }\end{array}$ & $\begin{array}{c}\text { Managers } \\
\text { vs. } \\
\text { Clerical } \\
\text { Workers }\end{array}$ & $\begin{array}{c}\text { Profs } \\
\text { vs. } \\
\text { Clerical } \\
\text { workers }\end{array}$ & $\begin{array}{c}\text { Supervisors } \\
\text { vs } \\
\text { Clerical } \\
\text { workers }\end{array}$ & $\begin{array}{c}\text { Managers } \\
\text { vs. } \\
\text { Clerical } \\
\text { Workers }\end{array}$ & $\begin{array}{c}\text { Profs } \\
\text { vs. } \\
\text { Clerical } \\
\text { workers }\end{array}$ & $\begin{array}{c}\text { Supervisors } \\
\text { vs } \\
\text { Clerical } \\
\text { workers }\end{array}$ \\
\hline Constant & $\begin{array}{c}-2.821 \\
(-48.34)\end{array}$ & $\begin{array}{c}-2.133 \\
(-53.40)\end{array}$ & $\begin{array}{c}-1.867 \\
(-43.77)\end{array}$ & $\begin{array}{c}-2.011 \\
(-14.05)\end{array}$ & $\begin{array}{c}-1.601 \\
(-15.72)\end{array}$ & $\begin{array}{c}-1.497 \\
(-14.14)\end{array}$ & $\begin{array}{c}-2.431 \\
(-18.42)\end{array}$ & $\begin{array}{c}-2.067 \\
(-20.72)\end{array}$ & $\begin{array}{c}-1.746 \\
(-17.18)\end{array}$ \\
\hline Age & $\begin{array}{l}0.0055 \\
(4.729)\end{array}$ & $\begin{array}{l}-0.0004 \\
(-0.487)\end{array}$ & $\begin{array}{l}0.0133 \\
(15.28)\end{array}$ & $\begin{array}{l}-0.0073 \\
(-2.955)\end{array}$ & $\begin{array}{l}-0.0106 \\
(-6.171)\end{array}$ & $\begin{array}{l}0.0068 \\
(3.745)\end{array}$ & $\begin{array}{l}0.0019 \\
(0.470)\end{array}$ & $\begin{array}{l}-0.0036 \\
(-1.890)\end{array}$ & $\begin{array}{l}0.0102 \\
(5.281)\end{array}$ \\
\hline Arts & $\begin{array}{c}1.010 \\
(30.01)\end{array}$ & $\begin{array}{c}2.283 \\
(89.06)\end{array}$ & $\begin{array}{l}0.5576 \\
(21.00)\end{array}$ & $\begin{array}{c}1.193 \\
(18.30)\end{array}$ & $\begin{array}{c}2.233 \\
(44.40)\end{array}$ & $\begin{array}{l}0.7452 \\
(15.01)\end{array}$ & $\begin{array}{l}0.8790 \\
(12.21)\end{array}$ & $\begin{array}{l}2.1292 \\
(37.32)\end{array}$ & $\begin{array}{l}0.5157 \\
(8.816)\end{array}$ \\
\hline Business & $\begin{array}{c}1.018 \\
(35.08)\end{array}$ & $\begin{array}{c}1.211 \\
(45.56)\end{array}$ & $\begin{array}{l}0.8109 \\
(38.64)\end{array}$ & $\begin{array}{l}1.1044 \\
(18.69)\end{array}$ & $\begin{array}{c}1.390 \\
(27.05)\end{array}$ & $\begin{array}{l}0.7301 \\
(16.98)\end{array}$ & $\begin{array}{l}0.9425 \\
(14.28)\end{array}$ & $\begin{array}{c}1.223 \\
(20.28)\end{array}$ & $\begin{array}{l}0.7283 \\
(14.29)\end{array}$ \\
\hline $\begin{array}{l}\text { Engineering } \\
\& \text { Science }\end{array}$ & $\begin{array}{l}0.9123 \\
(20.21)\end{array}$ & $\begin{array}{c}2.188 \\
(68.50) \\
\end{array}$ & $\begin{array}{l}0.4656 \\
(12.97) \\
\end{array}$ & $\begin{array}{l}0.9242 \\
(11.64)\end{array}$ & $\begin{array}{c}2.453 \\
(46.24) \\
\end{array}$ & $\begin{array}{l}0.4552 \\
(7.482)\end{array}$ & $\begin{array}{l}0.7162 \\
(6.869) \\
\end{array}$ & $\begin{array}{c}2.143 \\
(29.05)\end{array}$ & $\begin{array}{l}0.4892 \\
(5.868)\end{array}$ \\
\hline Health & $\begin{array}{l}0.3276 \\
(6.464)\end{array}$ & $\begin{array}{c}2.977 \\
(109.7)\end{array}$ & $\begin{array}{l}-0.3720 \\
(-8.764)\end{array}$ & $\begin{array}{l}0.2531 \\
(2.501)\end{array}$ & $\begin{array}{c}2.718 \\
(51.84)\end{array}$ & $\begin{array}{l}-0.2843 \\
(-3.594)\end{array}$ & $\begin{array}{l}0.0841 \\
0.729)\end{array}$ & $\begin{array}{c}2.681 \\
(44.44)\end{array}$ & $\begin{array}{r}-0.4353 \\
-(4.514)\end{array}$ \\
\hline $\begin{array}{l}\text { CMA } \\
\text { resident }\end{array}$ & $\begin{array}{c}0.5010 \\
(211.219) \\
\end{array}$ & $\begin{array}{l}0.4217 \\
(24.71)\end{array}$ & $\begin{array}{c}0.1330 \\
(7.93)\end{array}$ & $\begin{array}{l}-0.0126 \\
(-0.198)\end{array}$ & $\begin{array}{l}0.0520 \\
(1.058)\end{array}$ & $\begin{array}{l}-0.1214 \\
(-2.407)\end{array}$ & $\begin{array}{l}0.4776 \\
7.770) \\
\end{array}$ & $\begin{array}{l}0.4275 \\
(9.712)\end{array}$ & $\begin{array}{l}0.1734 \\
(3.880)\end{array}$ \\
\hline Married & $\begin{array}{l}0.1655 \\
(6.696)\end{array}$ & $\begin{array}{l}0.1025 \\
(5.739)\end{array}$ & $\begin{array}{l}0.1962 \\
(10.63)\end{array}$ & $\begin{array}{l}0.1809 \\
(3.512)\end{array}$ & $\begin{array}{l}-0.0203 \\
(-0.595)\end{array}$ & $\begin{array}{l}0.1247 \\
(3.331)\end{array}$ & $\begin{array}{l}0.1720 \\
(3.195)\end{array}$ & $\begin{array}{c}0.156193 \\
(3.975)\end{array}$ & $\begin{array}{l}0.2922 \\
(6.788)\end{array}$ \\
\hline $\begin{array}{l}\text { Self- } \\
\text { employed }\end{array}$ & $\begin{array}{c}1.867 \\
(36.99)\end{array}$ & $\begin{array}{l}0.7444 \\
(13.89)\end{array}$ & $\begin{array}{c}1.109 \\
(23.28)\end{array}$ & $\begin{array}{c}2.215 \\
(27.00)\end{array}$ & $\begin{array}{l}0.6965 \\
(7.726)\end{array}$ & $\begin{array}{c}1.165 \\
(14.26)\end{array}$ & $\begin{array}{c}1.996 \\
(16.78)\end{array}$ & $\begin{array}{l}0.8393 \\
(6.784)\end{array}$ & $\begin{array}{c}1.239 \\
(10.69)\end{array}$ \\
\hline $\begin{array}{l}\text { Language } \\
\text { Ability }\end{array}$ & $*$ & $*$ & $*$ & $\begin{array}{l}-0.5988 \\
(-3.500)\end{array}$ & $\begin{array}{c}-1.151 \\
(-6.963)\end{array}$ & $\begin{array}{l}-0.2428 \\
(--2.614)\end{array}$ & $*$ & $*$ & $*$ \\
\hline $\begin{array}{l}\text { Immigrant } \\
\text { cohorts }\end{array}$ & $*$ & $*$ & $*$ & $*$ & $*$ & $*$ & $*$ & $*$ & $*$ \\
\hline $1996-2000$ & $*$ & $*$ & $*$ & $\begin{array}{l}-0.7264 \\
(-9.966)\end{array}$ & $\begin{array}{l}-0.4170 \\
(-8.977)\end{array}$ & $\begin{array}{c}-0.5023 \\
(-9.27)\end{array}$ & $*$ & $*$ & $*$ \\
\hline 1991-1995 & $*$ & $*$ & $*$ & $\begin{array}{l}-0.8618 \\
(-12.18)\end{array}$ & $\begin{array}{c}-0.6550 \\
(-14.270\end{array}$ & $\begin{array}{l}-0.5065 \\
(-10.23)\end{array}$ & $*$ & $*$ & $*$ \\
\hline $1986-1990$ & $*$ & $*$ & $*$ & $\begin{array}{l}-0.5974 \\
(-8.501)\end{array}$ & $\begin{array}{l}-0.4265 \\
(-8.984)\end{array}$ & $\begin{array}{l}-0.2567 \\
(-5.198) \\
\end{array}$ & $*$ & $*$ & $*$ \\
\hline $\begin{array}{l}\text { Likelihood } \\
\text { ratio }\end{array}$ & \multicolumn{3}{|c|}{35375} & \multicolumn{3}{|c|}{8102} & \multicolumn{3}{|c|}{5669} \\
\hline $\mathrm{N}$ & \multicolumn{3}{|c|}{115197} & \multicolumn{3}{|c|}{31789} & \multicolumn{3}{|c|}{21109} \\
\hline
\end{tabular}

$\mathrm{t}$ ratios in parentheses

The general pattern of the estimates for men given in Table 3 is quite similar to that of women. One difference for the foreign-born is that not knowing an official language has a positive (and statistically significant) impact on the probability of being in the supervisors category relative to the clerical category. On the other hand, it is clear that established immigrants are more likely than more recent immigrants to be in all occupations relative to the clerical category. Again, this is suggestive of greater occupational mobility of men as length of residence increases.

\section{Simulations with Model}

Based on estimates of the logit model from the 2001 census, we simulate the occupational profiles of "equivalent" native-born and foreign-born men and women, as well as those native-born who are second-generation Canadians. By way of illustration, we consider individuals to be "equivalent" if they possess the following bundle of characteristics: they are married, CMA residents with a knowledge of English and/or French, are 45 years of age and not self-employed, and have a post-secondary degree/diploma in arts, humanities or social sciences (Arts). The results of this simulation are reported in Table 4. 
Table 3: Multinomial Logit Estimates of Occupational Choice - Men

\begin{tabular}{|c|c|c|c|c|c|c|c|c|c|}
\hline & \multicolumn{3}{|c|}{ Native-Born } & \multicolumn{3}{|c|}{ Foreign-Born } & \multicolumn{3}{|c|}{ Second-Generation } \\
\hline & $\begin{array}{c}\text { Managers } \\
\text { vs. } \\
\text { Clerical } \\
\text { workers } \\
\end{array}$ & $\begin{array}{c}\text { Profs } \\
\text { vs. } \\
\text { Clerical } \\
\text { workers } \\
\end{array}$ & $\begin{array}{c}\text { Supervisors } \\
\text { vs } \\
\text { Clerical } \\
\text { workers } \\
\end{array}$ & $\begin{array}{c}\text { Managers } \\
\text { vs. } \\
\text { Clerical } \\
\text { Workers } \\
\end{array}$ & $\begin{array}{c}\text { Profs } \\
\text { vs. } \\
\text { Clerical } \\
\text { workers } \\
\end{array}$ & $\begin{array}{c}\text { Supervisors } \\
\text { vs } \\
\text { Clerical } \\
\text { workers } \\
\end{array}$ & $\begin{array}{c}\text { Managers } \\
\text { vs. } \\
\text { Clerical } \\
\text { Workers } \\
\end{array}$ & $\begin{array}{c}\text { Profs } \\
\text { vs. } \\
\text { Clerical } \\
\text { workers } \\
\end{array}$ & $\begin{array}{c}\text { Supervisors } \\
\text { vs } \\
\text { Clerical } \\
\text { workers } \\
\end{array}$ \\
\hline Constant & $\begin{array}{c}-3.233 \\
(-68.27) \\
\end{array}$ & $\begin{array}{c}-2.573 \\
(-59.12) \\
\end{array}$ & $\begin{array}{c}-1.077 \\
(-30.67) \\
\end{array}$ & $\begin{array}{c}-1.899 \\
(-16.87) \\
\end{array}$ & $\begin{array}{c}-1.732 \\
(-17.21) \\
\end{array}$ & $\begin{array}{l}-0.5637 \\
(-6.402)\end{array}$ & $\begin{array}{c}-2.794 \\
(-26.15) \\
\end{array}$ & $\begin{array}{c}-2.140 \\
(-21.52) \\
\end{array}$ & $\begin{array}{l}-1.002 \\
(-11.32)\end{array}$ \\
\hline Age & $\begin{array}{c}0.01456 \\
(14.93) \\
\end{array}$ & $\begin{array}{l}-0.0026 \\
(-2.884) \\
\end{array}$ & $\begin{array}{l}0.0070 \\
(0.902) \\
\end{array}$ & $\begin{array}{l}-0.0023 \\
(-1.167) \\
\end{array}$ & $\begin{array}{r}-0.0126 \\
(-7.210) \\
\end{array}$ & $\begin{array}{l}0.0008 \\
(0.517) \\
\end{array}$ & $\begin{array}{l}0.0100 \\
(4.656) \\
\end{array}$ & $\begin{array}{l}-0.0053 \\
(-2.597) \\
\end{array}$ & $\begin{array}{l}-0.0020 \\
(-1.052) \\
\end{array}$ \\
\hline Arts & $\begin{array}{c}1.290 \\
(39.83) \\
\end{array}$ & $\begin{array}{c}2.487 \\
(84.56) \\
\end{array}$ & $\begin{array}{l}0.5664 \\
(19.14) \\
\end{array}$ & $\begin{array}{c}1.100 \\
(17.23) \\
\end{array}$ & $\begin{array}{c}2.433 \\
(41.56) \\
\end{array}$ & $\begin{array}{l}0.1901 \\
(3.246) \\
\end{array}$ & $\begin{array}{c}1.094 \\
(16.31) \\
\end{array}$ & $\begin{array}{c}2.167 \\
(34.46) \\
\end{array}$ & $\begin{array}{l}0.4585 \\
(7.076) \\
\end{array}$ \\
\hline Business & $\begin{array}{c}1.952 \\
(65.66) \\
\end{array}$ & $\begin{array}{c}2.062 \\
(63.32) \\
\end{array}$ & $\begin{array}{l}0.5210 \\
(16.58)\end{array}$ & $\begin{array}{c}1.702 \\
(30.33)\end{array}$ & $\begin{array}{c}2.123 \\
(35.15) \\
\end{array}$ & $\begin{array}{l}0.1781 \\
(3.073) \\
\end{array}$ & $\begin{array}{c}1.744 \\
(26.39)\end{array}$ & $\begin{array}{c}1.927 \\
(27.09)\end{array}$ & $\begin{array}{l}0.6550 \\
(7.963) \\
\end{array}$ \\
\hline $\begin{array}{l}\text { Engineering } \\
\text { \& Science }\end{array}$ & $\begin{array}{l}0.9667 \\
(41.12) \\
\end{array}$ & $\begin{array}{c}2.248 \\
(98.76) \\
\end{array}$ & $\begin{array}{c}1.249 \\
(73.13) \\
\end{array}$ & $\begin{array}{c}1.202 \\
(27.51) \\
\end{array}$ & $\begin{array}{c}2.754 \\
(61.000) \\
\end{array}$ & $\begin{array}{l}0.9262 \\
(27.67) \\
\end{array}$ & $\begin{array}{l}0.9859 \\
(18.42) \\
\end{array}$ & $\begin{array}{c}2.295 \\
(44.00) \\
\end{array}$ & $\begin{array}{c}1.291 \\
(29.80) \\
\end{array}$ \\
\hline Health & $\begin{array}{l}0.5292 \\
(5.448) \\
\end{array}$ & $\begin{array}{c}3.341 \\
(56.66) \\
\end{array}$ & $\begin{array}{r}-0.0947 \\
(-1.054) \\
\end{array}$ & $\begin{array}{l}0.5191 \\
(3.476) \\
\end{array}$ & $\begin{array}{c}3.328 \\
(34.96) \\
\end{array}$ & $\begin{array}{r}-0.6136 \\
(-3.721) \\
\end{array}$ & $\begin{array}{l}-0.0122 \\
(-0.049) \\
\end{array}$ & $\begin{array}{c}3.301 \\
(24.01) \\
\end{array}$ & $\begin{array}{l}0.0755 \\
(0.371) \\
\end{array}$ \\
\hline $\begin{array}{l}\text { CMA } \\
\text { resident }\end{array}$ & $\begin{array}{l}0.5589 \\
(28.02)\end{array}$ & $\begin{array}{l}0.5864 \\
(31.88) \\
\end{array}$ & $\begin{array}{l}-0.0492 \\
(-3.269) \\
\end{array}$ & $\begin{array}{l}0.0931 \\
(1.590)\end{array}$ & $\begin{array}{l}0.1623 \\
(3.123) \\
\end{array}$ & $\begin{array}{l}-0.2259 \\
(-5.008) \\
\end{array}$ & $\begin{array}{l}0.4936 \\
(9.617) \\
\end{array}$ & $\begin{array}{l}0.4768 \\
(10.04) \\
\end{array}$ & $\begin{array}{c}-0.071 \\
(-1.725) \\
\end{array}$ \\
\hline Married & $\begin{array}{l}0.7436 \\
(32.23) \\
\end{array}$ & $\begin{array}{l}0.2745 \\
(14.11) \\
\end{array}$ & $\begin{array}{l}0.3850 \\
(22.75) \\
\end{array}$ & $\begin{array}{l}0.4717 \\
(4.691) \\
\end{array}$ & $\begin{array}{l}0.0309 \\
(0.800) \\
\end{array}$ & $\begin{array}{l}0.2628 \\
(7.005) \\
\end{array}$ & $\begin{array}{l}0.8469 \\
(16.88) \\
\end{array}$ & $\begin{array}{l}0.2829 \\
(6.617) \\
\end{array}$ & $\begin{array}{l}0.4855 \\
(11.73) \\
\end{array}$ \\
\hline $\begin{array}{l}\text { Self- } \\
\text { employed }\end{array}$ & $\begin{array}{c}1.845 \\
(50.18)\end{array}$ & $\begin{array}{c}1.084 \\
(26.45) \\
\end{array}$ & $\begin{array}{c}1.011 \\
(28.15)\end{array}$ & $\begin{array}{c}1.982 \\
(32.67) \\
\end{array}$ & $\begin{array}{l}0.8184 \\
(12.06) \\
\end{array}$ & $\begin{array}{l}0.6996 \\
(10.99) \\
\end{array}$ & $\begin{array}{c}1.570 \\
(19.52) \\
\end{array}$ & $\begin{array}{l}0.0122 \\
(10.53) \\
\end{array}$ & $\begin{array}{l}0.9516 \\
(11.82) \\
\end{array}$ \\
\hline $\begin{array}{l}\text { Language } \\
\text { Ability }\end{array}$ & $*$ & $*$ & $*$ & $\begin{array}{l}-0.5806 \\
(-3.889)\end{array}$ & $\begin{array}{l}-0.9014 \\
(-5.243)\end{array}$ & $\begin{array}{l}0.3878 \\
(5.058)\end{array}$ & $*$ & $*$ & $*$ \\
\hline $\begin{array}{l}\text { Immigrant } \\
\text { cohorts }\end{array}$ & * & * & * & & & & * & * & * \\
\hline $1996-2000$ & $*$ & $*$ & * & $\begin{array}{l}-0.8783 \\
(-14.89) \\
\end{array}$ & $\begin{array}{c}-0.1758 \\
(-3.940) \\
\end{array}$ & $\begin{array}{l}-0.7939 \\
(-16.64) \\
\end{array}$ & * & $*$ & * \\
\hline 1991-1995 & $*$ & $*$ & $*$ & $\begin{array}{l}-0.6365 \\
(-11.52) \\
\end{array}$ & $\begin{array}{r}-0.3908 \\
(-7.974) \\
\end{array}$ & $\begin{array}{r}-0.5148 \\
(-11.69) \\
\end{array}$ & * & $*$ & $*$ \\
\hline $1986-1990$ & * & $*$ & $*$ & $\begin{array}{l}-0.6306 \\
(-10.95) \\
\end{array}$ & $\begin{array}{r}-0.3909 \\
(-7.974) \\
\end{array}$ & $\begin{array}{l}-0.3474 \\
(-7.856) \\
\end{array}$ & * & * & $*$ \\
\hline $\begin{array}{l}\text { Likelihood } \\
\text { ratio }\end{array}$ & & 34674 & & & 9942 & & & 5841 & \\
\hline $\mathrm{N}$ & & 123044 & & & 34302 & & & 22253 & \\
\hline
\end{tabular}

$\mathbf{t}$ ratios in parentheses

Confining our attention, for the moment, to just aggregate differences, it seems that men are more likely to be in management positions compared to "equivalent" females, regardless of which group they belong to. Thus, management positions do seem to be skewed in favour of males. But this advantage is not uniform across all male groups, with second-generation males and native-born clearly being more dominant in this category. It is the second generation males who are predicted to be in management with a probability of just under $24 \%$. The corresponding probability for foreign-born men is about $16 \%$. Among women, immigrants have the smallest probability of being in management (about 10\%), compared to $11.3 \%$ for both native-born in general and second generation native-born. At the other end, the clerical position is not fully dominated by women. While for each group, the probability of women being in clerical positions is higher compared to their male counterparts, foreign-born men are more likely to be in these positions than native-born and second-generation women. As far as the professions category is concerned, the native-born and second generation of either sex, are more likely to be in this category compared to foreign-born women and men, the probabilities for the latter being in the $35-36 \%$ range, compared to the $40-43 \%$ range for the former. Finally, there is not much difference in the predicted probabilities for the supervisors category across groups and sex, which vary in the $17-20 \%$ range.

Table 4 also allows us to examine how foreign-born profiles change as the length of residence in Canada increases. The predicted probabilities for the four immigrant cohorts generally suggest that the foreign-born show occupational mobility over time. For instance, foreign-born men of older vintage are predicted to have a greater chance of being managers compared to newer immigrant men. That is, there is upward mobility towards the probabilities of native- born and second-generation men; yet, even these older immigrant cohorts are still significantly less likely than native-born and second-generation men to be managers. In contrast, foreign-born 
women do appear to catch up to their native-born counterparts; that is, older cohorts of immigrant women are as likely as the native-born and second-generation women to be in management. In the supervisors category, the predicted probabilities of older immigrant men and women are very similar to those native born men and women, again pointing to convergence towards the occupational profiles of the native-born and second-generation Canadians. In the clerical category, again foreign-born women and men belonging to older cohorts are less likely to be in that category than newer cohorts, and this implies a movement towards native-born and second-generation probabilities. Finally, in the professionals category, new immigrants tend to be more concentrated than native-born and second-generation men, but length of residence narrows this gap, and this also true for foreign-born women.

Table 4: Predicted Probabilities (\%) by Occupation and Population Groups

\begin{tabular}{|l|c|c|c|c|}
\hline \multicolumn{1}{|c|}{ Category } & Managers & Professionals & Supervisors & Clerical \\
\hline Native-born men & 21.1 & 40.1 & 18.0 & 20.8 \\
\hline Foreign-born men & 15.8 & 36.1 & 17.5 & 30.6 \\
\hline Second-generation men & 23.6 & 37.4 & 17.3 & 21.6 \\
\hline Native-born women & 11.3 & 42.9 & 19.4 & 26.4 \\
\hline Foreign--born women & 9.8 & 34.5 & 19.1 & 36.5 \\
\hline Second-generation women & 11.3 & 42.9 & & 26.4 \\
\hline $\begin{array}{l}\text { Foreign-born by cohort } \\
\text { (women) }\end{array}$ & & & & \\
\hline $1996-2001$ & 10.1 & 46.2 & 10.9 & 32.8 \\
\hline $1991-1995$ & 13.2 & 38.3 & 17.0 & 333.8 \\
\hline $1986-1990$ & 11.1 & 37.3 & 17.7 & 34.6 \\
\hline Pre-1986 & 15.5 & 40.4 & & 26.5 \\
\hline $\begin{array}{l}\text { Foreign-born by cohort } \\
\text { (men) }\end{array}$ & & & & \\
\hline $1996-2001$ & 7.7 & 33.5 & 16.5 & \\
\hline $1991-1995$ & 7.3 & 28.8 & 20.0 & 42.3 \\
\hline $1986-1990$ & 8.3 & 31.5 & 20.0 & 46.1 \\
\hline Pre-1986 & 11.7 & 37.3 & & 31.0 \\
\hline
\end{tabular}

Overall, the occupational profiles of newer foreign-born men and women are quite different from those of the native-born and second-generation men and women, but as the length of residence in Canada increases, their profiles shift towards those of their native-born counterparts. Thus, immigrants are occupationally mobile. Further, the finding that second-generation occupational profiles of both and men are favourable in that they are most likely to be in managerial positions and least likely to be in clerical positions, suggest that whatever difficulties immigrants face in Canadian labour markets, these do not seem to passed on to their children.

\section{CONCLUSIONS}

This paper examined how the occupational patterns of the foreign-born differ from those of the native-born, whether the length of residence in Canada has implications for the occupational mobility of the former, and what role gender plays in this regard. We also studied the inter-generational transfer of occupational status by comparing the occupational profiles of foreign-born and second-generation Canadians. These issues were examined by estimating a multinomial model of occupational choice using data from the 2001 Canadian Census. The model was used to predict occupational choices of the afore-mentioned population groups to examine 1) how the occupational profile of otherwise similar native-born and second-generation men and women differ from those of the their foreign-born counterparts and 2) how the length of residence in Canada affects the occupational mobility of immigrant men and women as they become more accustomed to Canadian labour markets.

Our results suggest that not knowing at least one of English and French, and not having a post-secondary education makes it more likely that men and women, foreign-born or native-born, are more likely to be in clerical and other lower skilled occupations. Typically, men are more likely to be managers, while women are more concentrated in clerical and other lower-skilled positions. However, the impact of gender also depends upon whether an individual is native-born, second generation or foreign-born. Relative to other groups, foreign-born women are the most likely to be in clerical positions, while second-generation and native-born men most likely are in 
management. We also find that the length of residence matters. Older and more established immigrants, men and women, seem to have quite different profiles from new immigrants, but profiles that are closer to those of nativeborn and second generation Canadians. This suggests that immigrants do display occupational mobility. But some gaps persist. For instance, foreign-born men are still much less likely to be in managerial positions, regardless of how long they have been in Canada. Women do better in this regard.

In conclusion, we note that the occupational outcomes of second-generation Canadians are clearly more favourable than that of new immigrants. This would imply that difficulties that immigrants face in labour markets may not be passed on to their children. In that event, public policy could be focused on those immigrant groups that may be disadvantaged in that their occupational choices push them into lower skilled employment because some occupations are blocked due to non-recognition of foreign credentials, or language difficulties.

\section{AUTHOR INFORMATION}

Najma R. Sharif is Associate Professor in the Department of Economics in the Sobey School of Business at Saint Mary's University, Halifax, Canada. She obtained her Ph.D in Economics from McMaster University in 1992. Her current research interests include the labour market outcomes of immigrants; the role of micro insurance in microenterprise development in developing countries; education and poverty reduction in developing countries: alternate delivery models, with a focus on gender and the quality vs. quantity issue. She teaches courses in Development Economics, Social Cost-Benefit Analysis, and Monetary Economics, in addition to introductory theory courses in Economics.

\section{REFERENCES}

1. Aydemir, A. and A. Sweetman (2006), "First and Second-Generational Educational Attainment and Labor Market Outcomes: A Comparison of the United States and Canada, IZA Discussion Paper 2298, Institute for the Study of Labour, Bonn, Germany.

2. Baker, M. and Benjamin, D. (1994), "The Performance of Immigrants in the Canadian Labour Market", Journal of Labour Economics, 12: 369-405.

3. Beach, Charles M. and C. Worswick (1993), "Is There a Double-Negative Effect on the Earnings of Foreign-born Women," Canadian Public Policy, XIX (1), 36-53.

4. Bloom, David E. and Gunderson, M., (1990), "An Analysis of the Earnings of Canadian Immigrants", In Abowd, J.M. and Freeman, R.B. (eds), Immigration, Trade and Labour Markets, Chicago: University of Chicago Press.

5. Borjas, George J., (1985), “Assimilation, Changes in Cohort Quality, and the Earnings of Immigrants”, Journal of Labour Economics, 3: 463-489.

6. Boyd, Monica (2000), "Matching Workers to Work: The Case of Asian Immigrant Engineers in Canada," Working Paper No.14, The Center for Comparative Immigration Studies, University of California-San Diego.

7. $\quad$ Greene, William .H., (1997), Econometric Analysis, Prentice-Hall: New Jersey.

8. Hum, D. and Simpson, W., (2004)," Economic Integration of Immigrants to Canada: A Short Survey", Canadian Journal of Urban Research, 13: 46-61.

9. Prescott David and Wandschneider, B., (1995), "The Assimilation of Immigrants in the Canadian Labour Market: 1981-1990”, Discussion Paper No. 1995-11, University of Guelph, Guelph, Canada.

10. Schmidt, Peter and Robert P. Strauss, (1975), "The Prediction of Occupation Using Multiple Logit Model," International Economic Review, 16:2, 471-486.

11. Sharif, Najma R., and Atul Dar (2007), “An Empirical Investigation of the Impact of Imperfect Information on Wages in Canada," Review of Applied Economics, 3:1-2, 137-155.

12. Sharif, Najma R., (2006), The Labour Market Adjustment of Foreign-Born Workers in Canada: A Multinomial Logit Model of Employment Status," International Business \& Economics Research Journal, 5:12, 39-47.

13. Worswick, C., (1996), "Immigrant Families in the Canadian Labour Market", Canadian Public Policy, 12 : 378-396. 